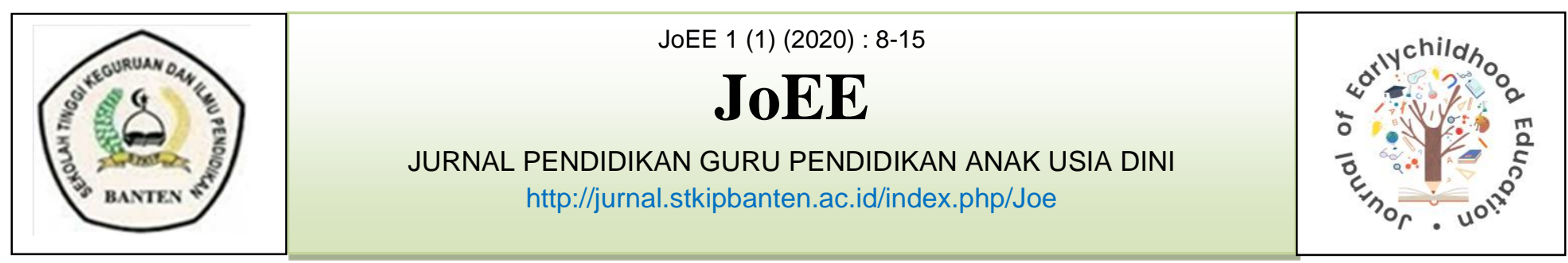

\title{
ANALISIS MODEL PEMBELAJARAN MAKE A MATCH TERHADAP KEMAMPUAN MENGENAL ANGKA ANAK USIA 4-5
}

\author{
Nia Kurniasih \\ kurniasihnia@gmail.com \\ Pendidikan Guru Pendidikan Anak Usia Dini \\ Sekolah Tinggi Keguruan dan Ilmu Pendidikan Banten
}

\begin{abstract}
Abstrak
Penelitian ini adalah penelitian studi literatur yang bertujuan untuk mengetahui peningkatan kemampuan mengenal angka setelah diterapkan model pembelajaran make a match,objek penelitian ini adalah jurnal nasional, artikel dan buku-buku terkait, teknik pengumpulan data pada penelitian ini adalah analisis kualitatif deskriftif. Hasil analisis pada penelitian ini menunjukkan bahwa terjadi peningkatan menggunakan model pembelajaran make a match, rata-rata persentase perkembangan kognitif mengenal angka melalui model make a match peneliti mendapatkan hasil peningkatan dari tiga sumber jurnal setelah diakumulasi yaitu dari sebelumnya $44,45 \%$ sesudah menggunakan model pembelajaran make a match menjadi $85,37 \%$, dengan nilai rata-rata peningkatan $35,25 \%$, sehingga dapat disimpulkan bahwa model pembelajaran make a macth dapat meningkatkan kemampuan mengenal angka.
\end{abstract}

Kata kunci: model Make a math; kemampuan kognif; mengenal angka.

\section{PENDAHULUAN}

Pendidikan Anak Usia Dini (PAUD) merupakan jenjang pendidikan yang diperuntukan bagi anak- anak sebelum memasuki kejenjang selanjutnya yaitu Sekolah Dasar. Melalui Pendidikan Anak Usia Dini anak dapat dirangsang untuk meningkatkan kemampuan dari berbagai aspek perkembangannya sesuai usia dan tingkat perkembangannya. Pendidikan anak usia dini adalah pendidikan yang diselenggarakan dengan tujuan memfasilitasi pertumbuhan dan perkembangan anak secara menyeluruh atau menekankan pada pengambangan kepribadian dan potensi secara maksimal.

Pendidikan anak usia dini dapat diartikan sebagai salah satu bentuk penyelenggaraan pendidikan yang menitikberatkan pada peletakan dasar kearah pertumbuhan dan perkembangan, baik koordinasi motorik, kecerdasan emosi, kecerdasan jamak maupun kecerdasan spiritual. Sesuai dengan keunikan dan pertumbuhan anak usia dini, penyenggaraan anak usia dini disesuiakan 
dengan tahap-tahap perkembangan yang dilalui oleh anak usia dini ${ }^{1}$

Berdasarkan UU no 20 tahun 2003 pasal 1 butir 14 Pendidikan anak usia dini adalah suatu upaya pembinaan yang ditunjukkan anak sejak lahir sampai dengan usia enam tahun yang dilakukan dengan pemberian rangsangan pendidikan untuk membantu pertumbuhan dan perkembangan jasmani dan rohani agar anak memliki kesiapan dalam memasuki pendidikan lebih lanjut.

Anak usia dini berada pada tahap pertumbuhan dan perkembangan yang paling pesat, baik dari segi fisik maupun mental, selain itu pertumbuhan dan perkembangan fisik, perkembangan motorik, moral, sosial, emosional, kognitif dan juga bahasa berlangsung sangat cepat, aspek- aspek perkembangan tersebut tidak berkembang secara sendiri- sendiri melaikan saling terjalin satu dengan yang lainnya.

Berdasarkan Peraturan menteri pendidikan dan Kebudayaan Republik Indonesia Nomor 137 tahun 2014 BAB 1, Pasal I, butir 10, Tentang Standar Nasional Pendidikan Anak Usia Dini bahwa "Pendidikan Anak Usia dini adalah suatu upaya pembinaan yang ditunjukan kepada anak sejak lahir sampai usia 6 tahun yang dilakukan melalui pemberian rangsangan pendidikan untuk membantu pertumbuhan dan perkembangan jasmani dan rohani agar anak memiliki kesiapan dalam memasuki pendidikan lebih lanjut".2

Piaget dalam Novi Mulyani mengemukakan bahwa pengetahuan anakanak disusun dalam 3 katagori, pertama pengetahuan fisik, anak-anak belajar tentang objek dilingkungan mereka secara fisik manipulasi objek, mereka mulai menyusun konsep mental tentang bentuk, ukuran, dan warna objek. Kedua

\footnotetext{
${ }^{1}$ Suyadi dan Maulidya Ulfa, Konsep Dasar PAUD, (Bandung: PT Remaja Rosdakarya, 2013), hlm. 17 2 . Peraturan Mentri Pendidikan dan kebudayaan Republik Indonesia No. 137, Tahun 2014 tentang Standar Nasional Pendidikan Anak Usia Dini.
}

pengetahuan logis- matematis, anak-anak menyusun hubungan tentang benda- banda seperti sama dan berbeda, lebih dan kurang, mana yang sekelompok atau sejenis, berapa banyak dan lainnya. Ketiga pengetahuan sosial, anak-anak mempelajari aturan bagi prilaku dan pengetahuan tentang tindakan orang-orang dengan kerlibatan mereka dengan masyarakat dilingkungan. Guru perlu merancang pembelajaran untuk mengenalkan angka kepada anak-anak dengan baik sehingga mampu menumbuhkan pemahaman tentang angka lebih bermakna dalam situasi yang menyenangkan, suasana belajar harus diciptakan melalui kegiatan permainan yang sesuai dengan karakteristik dunia anak yaitu dunia bermain.

Dalam penelitian ini peneliti tertarik untuk menggunakan Model pembelajaran make a match untuk mengenalkan angka pada anak usia 4-5 tahun. Model pembelajaran make a match (mencocokkan /mencari pasangan) sebagai pembelajaran yang efektif untuk mengenalkan angka. Kartu angka dapat digunakan sebagai alat peraga sekaligus dapat untuk alat permainan dalam kegiatan pembelajaran.

Bermain atau permainan
merupakan cara yang tepat untuk mengembangkan kemampuan bahasa anak usia dini terutama dalam pengenalan angka, mengingat anak usia dini adalah usia bermain, maka upaya menciptakan suasana belajar dapat diwujudkan dalam model pembelajaran make a macth permainan tebak angka, mencocokkan atau mencari pasangan menggunakan kartu angka. Dengan model make a match diharapkan dapat memberikan nilai lebih kepada siswa untuk meningkatkan kemampuan mengenal angka. 
Karna Sekolah Dasar (SD) sekarang ini sangat mengutamakan siswa yang sudah dapat mengenal huruf dan angka, dan berdasarkan hal tersebut orang tua juga menginginkan anak yang sudah disekolahkan di TK sudah dapat mengenal angka sebagai matematika dasar dengan harapan agar anak lebih mudah dalam menerima pembelajaran di Sekolah Dasar dalam pembelajaran berhitung. Bermain dengana tidak ada pemakasaan dan penekanan akan membuat anak cepat bosan sehingga anak dengan mudah dapat mengenal angka sesuai yang diharapkan karna dilakukan dengan hati yang senang.

Identifikasi Masalah berdasarkan latar belakang yang telah diuraikan diatas, maka dapat ditentukan masalah sebagi berikut: Mengenal angka merupakan pengetahuan dasar pada berhitung permulaan. Salah satu indikator kognitif anak usia 4-5 tahun adalah mengenal lambang bilangan.. Batasan Masalah

Berdasarkan identifikasi masalah yang ada di atas tidak semua masalah akan diteliti, sehingga dalam penelitian ini peneliti membatasi masalah pada kemampuan mengenal angka 1-10 melalui model pembelajaran make a match.

Rumusan masalah yang diajukan pada penelitian ini adalah "apakah ada peningkatan kemampuan mengenal angka peserta didik kelompok usia 4-5 tahun menggunakan Model pembelajaran make a match ?"

Tujuan Penelitian Berdasarkan rumusan masalah diatas, maka tujuan peneliti ini adalah untuk mengetahui apakah ada peningkatan kemampuan mengenal angka anak usia 4-5 tahun dengan menggunakan model pembelajaran Make a Match.

Menurut Agung tri harsono matematika di PAUD adalah kegiatan belajar tentang konsep matematika melalui aktivitas bermain dalam kehidupan sehari-hari dan bersifat ilmiah. Menurut Jean Piaget tentang intelektual anak usia 27 tahun pada tahap praoperasional, tahap penguasaan kegiatan berhitung/matematika pada anak usia taman kanak-kanak akan melalui tahap sebagai berikut: Tahap konsep / pengertian, pada tahap ini anakanak berkreasi untuk menghitung segala macam benda-benda yang dilihatnya. tahap transmisi peralihan merupakan masa peralihan dari konkret kelambang yaitu saat anak benar-benar memahami, mampu menghitung kesesuaian antara benda yang dihitung dan bilangan yang disebutkan, Tahap lambang Tahap ini anak sudah diberi kesempatan menulis sendiri tanpa pemaksaan, yakni berupa lambang bilangan, bentuk-bentuk dan sebagian jalur-jalur dalam mengenal kegiatan berhitung dan matematika. Piaget dalam Ahmad Susanto menyatakan bahwa tahap praoperasioanal pada usia 2-7 tahun didalam berfikirnya tidak didasarkan pada keputusan yang logis melainkan hanya dilihat seketika, prilaku yang didapat pada perkembangan anak usia ini, antara lain anak menggunakan kata-kata untuk menyatakan suatu benda, menghitung secara sederhana, anak secara konkret, dapat melakukan perbandingan lebih tinggi, dan lebih banyak, pada tahap praoperasional anak lebih sukar melihat hubungan dan mengambil kesimpulan secara konsisten.

Pengertian model Pembelajaran Menurut Kusnadi model pembelajaran adalah suatu perencanaan atau pola yang 
digunakan sebagai pedoman dalam merencanakan pembelajaran di kelas atau disuatu perencanaan atau pola yang dapat kita gunakan untuk mendisain pola-pola mengajar secara tatap muka didalam kelas dan untuk menentukan material atau perangkat pembelajaran.

Menurut Supriono dalam kusnadi sebuah model pembelajaran adalah sebuah rencana atau pola yang mengorganisasi pembelajaran dalam kelas dan menunjukkan cara penggunaan materi pembelajaran. Menurut Joyce model pembelajaran adalah suatu perencanaan pola yang digunakan di kelas atau dipelajaran dalam tutorial dan untuk menentukan perangkat-perangkat pembelajaran

Menurut Noer Khosim model pembelajaran make a macth model pembelajaran mencari pasangan,setiap siswa mendapat sebuah kartu (bisa soal atau jawaban) lalu secepatnya mencari pasangan yang sesuai dengan kartu yang ia pegang, suasana pembelajaran make a match akan riuh, tetapi sangat asik dan menyenangkan.

Menurut Kusnadi model pembelajaran kooperatif tipe make a macth adalah suatu teknik pembelajran make a macth adalah suatu teknik mencari pasangan sambil belajar mengenai suatu konsep atau topik dalam semua mata pelajaran dan tingkatan kelas.

Menurut Rusman metode make a match (membuat pasangan) merupakan salah satu jenis dari metode dalam pembelajaran kooperatif, salah satu keunggulan teknik ini adalah peserta didik mencari pasangan sambil belajar mengenai suatu konsep atau topik dalam suasana yang menyenangkan. ${ }^{3}$

Anita Lie dalam Agus krisno menyatakan bahwa metode pembelajaran tipe make a macth atau bertukar pasangan merupakan teknik belajar yang memberi kesempatan siswa untuk bekerja sama dengan orang lain. Teknik ini dapat digunakan dalam semua mata pelajaran dan untuk semua tingkatan semua anak didik.

Langkah-langkah pembelajaran make a macth (membuat pasangan) adalah sebagai berikut : 1. Guru menyiapkan beberapa konsep/topik yang cocok untuk sesi review (satu sisi kartu soal dan satu sisi berupa kartu jawaban beserta gambar) 2. Setia peserta didik mendapat suatu kartu dan memikirkan jawaban atau soal dari kartu yang dipegang 3. Peserta didik mencari pasangan yang mempuanyai kartu yang cocok dengan kartunya (kartu soal/jawaban) peserta didik yang dapat mencocokkan kartunya sebelum batas waktu diberi point 4. Setelah itu babak dicocokkan lagi agar tiap peserta didik mendapat kartu yang berbeda dari sebelumnya.

Kelebihan dan Kekurang Model pembelajaran make a match (MaM) menurut Moch. Krino Budianto Kelebihan dan kekurangan model make a match diantaranya: 1. Dapat menigkatkan aktivitas belajar siswa, baik secara kognitif maupun fisik 2. Karena ada unsur permaianan metode ini menyenangkan 3 . Meningkatkan pemahaman siswa terhadap materi yang dipelajari dan dapat meningkatkan motivasi balajar siswa. 
5.Efektif sebagai sarana melatih keberanian siswa untuk tampil presentasi 5. Efektif melatih siswa menghargai waktu untuk belajar.

Kekurangan model pembelajaran make a match (MaM) 1. Jika model pembelajaran ini tidak dipersiapkan dengan baik, akan banyak waktu yang terbuang 2. Pada awal-awal penerapan metode, banyak siswa yang akan malu berpasangan dengan lawan jenisnya 3. Jika guru tidak mengarahkan siswa dengan baik, akan banyak siswa yang kurang memperhatiakan pada saat presentasi pasangan 4. Guru harus hati-hati dan bijaksana saat memberi hukuman pada siswa yang tidak mendapat pasangan, karena mereka bisa malu 5. Menggunakan model pembelajaran ini terus menerus akan menimbulkan kebosanan.

Penelitian yang Relevan 1. Putu Diah Febriani dalam penelitiannya untuk mengetahui peningkatan kemampuan mengenal lambang bilangan setelah diterapkan metode pembelajaran Make A Match pada anak kelompok B semester II di TK Dharma Sentana Desa Candiksuma Negara Tahun Pelajaran (2014/2015) 2. Pengaruh model pembelajaran make a match terhadap kemampuan berhitung permulaan pada anak kelompok A (jurnal) oleh Ketut Pudjawan1 DKK 3. Penerapan model pembelajaran make a match untuk meningkatkan perkembangan kognitif dalam mengenal lambang bilangan oleh $\mathrm{Ni}$ Md Desy Pratiwi Handaryani DKK.(jurnal)

4. Penerapan model make a match berbantuan media kartu angka untuk meningkatkan perkembangan kognitif anak ditk buana sutha nugraha Selemadeg, oleh Gusti Ayu Made DKK 5. Penerapan metode pembelajaran make a match dalam meningkatkan hasil matematika untuk materi bangun datar pada siswa kelas $1 \mathrm{MI}$ Baitul Halim Khusus Yatim Piatu Palembang, Fakultas tarbiah dan keguruan Universitas Islam Negri (UIN) Raden Fatah Palembang, 2017 oleh Nur azizah.

Kerangka berfikir tabel.1

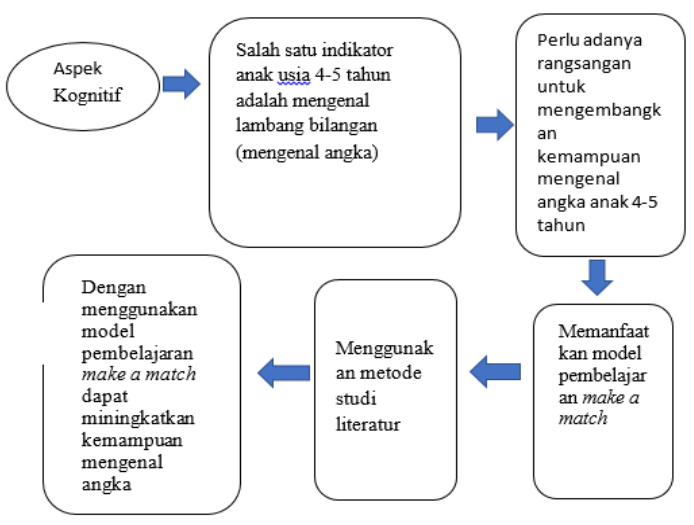

METODE

Jenis penelitian ini peneliti menggunakan studi Literatur yaitu mengumpulkan data atau karya tulis ilmiah yang berkaitan dengan objek penelitian atau pengumpulan data yang bersifat kepustakaan, atau telaah yang dilaksanakan untuk memecahkan masalah yang pada dasarnya tertumpu pada penelaahan kritis dan mendalam terhadap bahan-bahan pustaka yang relevan.

Dalam penelitian ini pendekatan yang dilakukan adalah melalui pendekatan kualitatif, artinya data yang dikumpulkan bukan berupa angka- angka, melainkan data tersebut berasal dari kajian kepustakaan.

Desai penelitian table. 2

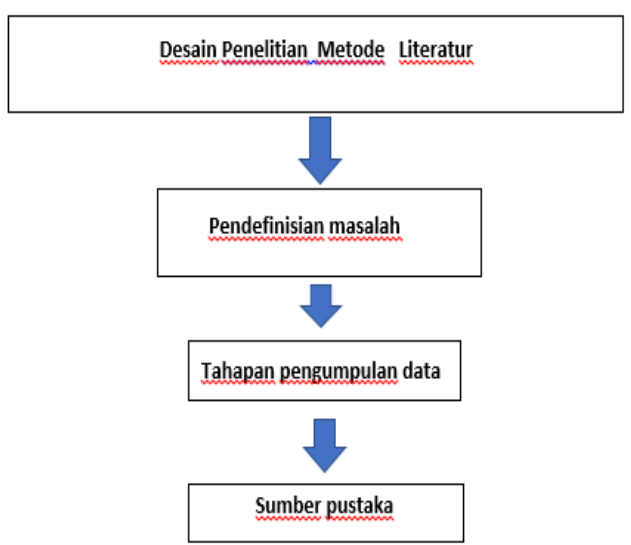




\section{HASIL DAN PEMBAHASAN}

Perkembangan kognitif anak usia 4-5 tahun salah satunya adalah mengenal lambang bilangan atau mengenal angka, penerapan model pembelajaran make a match terhadap peningkatakan kemampuan mengenal angka anak usia 4-5 tahun sangat berpengaruh terhadap peningkatan mengenal lambang bilangan atau mengenal angka,melalui metode studi literatur yang bersumber dari 3 jurnal nasional bahwa dengan menggunakan model pembelajaran make a match dapat meningkatkan kemampuan mengenal lambang bilangan, dengan rata-rata menegalami peningkatan. mengujian terhadap penelitian ini objek penelitian diambil dari sumber data skunder, obyek penelitiannya digali melalui beragam informasi kepustakaan baik itu buku, ensiklopedi, jurnal ilmiah, koran, majalah, dan dokumen-dokumen lainnya yang berhubungan dengan model pembelajaran make a match.yang diambil dari bukubuku terkait jurnal dan penelitian yang relevan.

Adapun idientitas objek sumber hasil penelitian yang dirujuk pada penelitian ini adalah: 1. jurnal Erniy purwaningsi udul, implementasi model make a match dalam mengembangkan kemampuan kognitif anak mengenal lambang bilangan pada kelompok a tk guyub mentari mataraman kabupaten banjar 2.jurnal Ni md desi pratiwi (2018) judul, penerapan model pembelajaran make a match untuk meningkatkan perkembangan kognitif dalam mengenal lambang bilangan 3.jurnal : Putu diah febriani, Desak putu parmiti, nice maylani asril (2015). judul penerapan metode make a match untuk meningkatkan kemampuan mengenal lambang bilangan paa anak kelompok $\mathrm{b}$ di tk dharma sentana candiksuma. Gambaran umum model pembelajaran make a match adalah suatu model pembelajaran mencari pasangaan atau mencocokkan, dimana pada prosesnya setiap siswa diberikan sebuah kartu (bisa berupa jawaban atau soal) lalu secepatnya mencari pasangan yang sesuia dengan kartu yang dipegang, pada penerapan model pembelajaran ini siswa diajak aktif selama proses kegiatan berlangsung.

Indikator mengenal angka dalam penelitian ini yaitu : a) Anak mampu mengenal angka 1-10 b) Anak mampu mencocokkan angka pelajaran mengenal angka akan menarik dengan model pembelajran make a match sehingga perkembangan kognitif siswa dalam mengenal lambang bilangan atau mengenal angka akan berkembang secara optimal.

\begin{tabular}{|c|c|c|c|c|c|}
\hline $\begin{array}{l}\text { Kods } \\
\text { data }\end{array}$ & $\begin{array}{c}\text { Variable } \\
\text { terkait }\end{array}$ & $\begin{array}{c}\text { Metode } \\
\text { penelitian }\end{array}$ & $\begin{array}{l}\text { Jumlah } \\
\text { Sampel }\end{array}$ & Hasil & Keterangan \\
\hline Jurnal 1 & $\begin{array}{l}\text { Peningkatica } \\
\text { n mengenal } \\
\text { lambang } \\
\text { bilangan }\end{array}$ & PTK & $\begin{array}{c}20 \\
\text { anak }\end{array}$ & $\begin{array}{l}\text { Skor pre test } \\
\text { sebesar } 35 \% \\
\text { menjadi } 95 \%\end{array}$ & $\begin{array}{l}\text { Terjadi } \\
\text { Peningkatan }\end{array}$ \\
\hline Jurnal 2 & $\begin{array}{l}\text { Meningkatk } \\
\text { an kognitif } \\
\text { mengenal } \\
\text { lambang } \\
\text { bilangan }\end{array}$ & PTK & 18 & $\begin{array}{l}\text { Skcor pre test } \\
\text { sebesar } \\
65,25 \% \\
\text { dengan } \\
\text { kriteria sedang } \\
\text { menjadi } \\
80,50 \% \\
\text { dengan } \\
\text { peningkatan }\end{array}$ & $\begin{array}{l}\text { Terjadi } \\
\text { Peningkatan }\end{array}$ \\
\hline Jurnal3 & $\begin{array}{l}\text { Meningkatk } \\
\text { an } \\
\text { kemampuan } \\
\text { mengenal } \\
\text { lambang } \\
\text { bilangan }\end{array}$ & PTK & & $\begin{array}{l}\text { Skor pre test } \\
\text { sebesar } 53,1 \% \\
\text { menjadi } \\
80,62 \%\end{array}$ & $\begin{array}{l}\text { Terjadi } \\
\text { Peningkatan }\end{array}$ \\
\hline
\end{tabular}

Kode MI menunjukkan pari hasil observasi yang dilakukan pada tanggal 25 Juli 2013 terhadap bidang pengembangan kognitif dengan indikator 
menghubungkan/memasangkan lambang bilangan dengan benda hasilnya hanya 5 orang atau $25 \%$ anak yang memiliki nilai bintang $* * *$. Maka dipilihlah modek make a match untuk mengembangkan kemampuan mengenal lambang bilangan melalui penelitian tindakan kelas. Hasil pengembangan kognitif anak mengalami peningkatan dalam hal ketepatan dan kecepatan anak menghubungkan gambar dengan lambang bilangan, pencapaian kemampuan kognitif anak dalam ketepatan anak menghubungkan gambar dengan lambang bilangandi siklus I hanya mencapai $35 \%$, meningkat pada siklus II menjadi $95 \%$ yang secara klasikal terjadi peningkatan yang signifikan .

Kode M2 yang dilakuakn oleh Ni md desy pratiwi handayani menyatakan bahwa 18 orang siswa, yang terdiri dari 8 orang anak perempuan dan 10 orang anak laki-laki. Metode analisis yang digunakan adalah metode analisis statistik deskriptif dan metode analisis deskriptif kuantitatif.Hasil analisis data pada penelitian ini menunjukkan bahwa terjadi peningkatan rata-rata persentase perkembangan kognitif dalam mengenal lambang bilangan pada anak kelompok A1 sebesar $15,25 \%$. Hal ini dapat dilihat dari adanya peningkatan rata-rata persentase perkembangan kognitif dalam mengenal lambang bilangan anak pada siklus I sebesar 65,25\% dengan kriteria sedang menjadi $80,50 \%$ pada siklus II dengan kriteria tinggi. Dengan demikian, dapat disimpulkan bahwa penerapan model pembelajaran make a matchdapat meningkatkan perkembangan kognitif dalam mengenal lambang bilangan anak Kelompok A1 TK Kartika VII-3 Singaraja Tahun Pelajaran 2018/2019.
Pada kode M3 yang diteliti oleh Putu diah febriani menyatakan Subjek penelitiannya adalah anak kelompok B TK Dharma Sentana Candikusuma Negara yang berjumlah 20 orang. Data penelitian tentang kemampuan mengenal lambang bilangan dikumpulkan dengan metode observasi dengan instrument berupa lembar format observasi. Data hasil penelitian dianalisis dengan menggunakan metode analisis statistik deskriptif dan metode analisis deskriptif kuantitatif. Hasil analisis data menunjukkan bahwa terjadi peningkatan kemampuan mengenal lambang bilangan dengan penerapan metode pembelajaran Make A Match pada siklus I sebesar 53,1\% yang berada pada kategori rendah ternyata mengalami peningkatan yang sangat signifikan pada siklus II menjadi 80,62\% yang tergolong pada kategori tinggi. Jadi, terjadi peningkatan kemampuan mengenal lambang bilangan pada anak sebesar $27,52 \%$.

\section{PENUTUP}

\section{Simpulan}

Terdapat peningkatan berdasarkan hasil analisis tentang model pemebelajan make a match terhadap kemampuan mengenal angka anak usia 4-5 tahun, dimana hasil penelitian yang peneliti dapatkan adalah bahwa setiap penelitian yang telah dilakukan memperoleh hasil persentase yang menunjukan adanya peningkatan hasil belajar siswa PAUD, serta dapat disimpulkan bahwa: 1) Kode MI skor pre test menunjukkan data dari data $35 \%$ menjadi $95 \%$ mengalami peningkatan $60 \%$. 2)Kode M2 skor pre test menunjukkan dari data $65,25 \%$ menjadi $80,50 \%$ menjadi $15,25 \%$. 3) Kode M3 skor pre test menunjukkan dari data 
$44,45 \%$ menjadi $85,37 \%$ mengalami peningkatan $27,52 \%$

\section{Saran}

Berdasarkan hasil penelitian dengan menggunakan model pembelajaran make a match terhadap kemampuan mengenal angka 4-5 tahun maka peneliti menagujukan beberapa saran diantaranya:

1. Sebaiknya bagi guru taman kanakkanak untuk memili model pembelajaran yang menyenangkan dan dapat merangsang keaktifan anak usia dini, agar dapat mempengaruhi hasil belajar siswa, sehingga berdampak positif pada anak itu sendiri dan bagi sekolah.

2. Hendaknya pihak sekolah memperhatikan fasilitas, sara dan prasana agar dapat menunjang kebutuhan guru untuk mengembangkan model pembelajaran yang telah ada.

3. Agar pembelajaran yang dilaksanakan berjalan sesuai dengan perkembangan yang ada, seyogyanya pihak sekolah memfasilitasi guru untuk mengikuti pelatihan-pelatihan untuk mengembangkan potensi guru.

\section{DAFTAR PUSTAKA}

Triharso, Agung, (2013). Permainan Kreatif dan Edukatif untuk Anak Usia Dini, Yogyakartra: Permainan Matematika dan Sains. Alkhosim, Noer. (2019). Belajar dan Pembelajaran yang menyenangkan. Surya Media Pulishing

Budianto, Agus Krisno. (2019). Sintaks 45 Metode Pembelajran. Malang : universitas Muhammadiah

Peraturan Mentri Pendidikan dan kebudayaan Republik Indonesia
No. 137, Tahun 2014 tentang Standar Nasional Pendidikan Anak Usia Dini.

Erniy Purwasih (2014) Implementasi model make a match dalam mengembangkan kemampuan kognitif anak mengenal lambang bilangan pada kelompok $A$ tk guyub mentari mataraman kabupaten

banjar.file:///D:/SKRIPSIKU/BAB $\% 2013 \% 20 \% 20$ SETELAH\%20SE

MPROP/kumpulan\%20jurnal\%20p df/2148-5918-1-SM\%20(4)

Febriani Diah Putu Dkk. (2015) Penerapan metode make a match untuk meningkatkan Kemampuan mengenal lambang bilangan pada anak kelompok https://ejournal.undiksha.ac.id/inde x.php/JJPAUD/article/view/6026

Handaryani Ni Md Desy Pratiwi DKK.,(2018) Penerapan model pembelajaran make a match untuk meningkatkan perkembangan kognitif dalam mengenal lambang bilangan ..(jurnal). https://ejournal.undiksha.ac.id/inde x.php/JIPPG/article/view/16452/12 $\underline{302}$ 